Discussion

Papers

Measuring Unmeasurable:

How to Map Laws to Numbers

Using Leximetrics 
Opinions expressed in this paper are those of the author(s) and do not necessarily reflect views of the institute.

IMPRESSUM

(C) DIW Berlin, 2021

DIW Berlin

German Institute for Economic Research

Mohrenstr. 58

10117 Berlin

Tel. +49 (30) $89789-0$

Fax +49 (30) $89789-200$

http://www.diw.de

ISSN electronic edition 1619-4535

Papers can be downloaded free of charge from the DIW Berlin website:

http://www.diw.de/discussionpapers

Discussion Papers of DIW Berlin are indexed in RePEc and SSRN:

http://ideas.repec.org/s/diw/diwwpp.html

http://www.ssrn.com/link/DIW-Berlin-German-Inst-Econ-Res.html 


\title{
Measuring unmeasurable: How to map laws to numbers using leximetrics ${ }^{\text {th }}$
}

\author{
Konstantin A. Kholodilin ${ }^{\mathrm{a}, \mathrm{b}}$, Linus Pfeiffer ${ }^{\mathrm{a}}$ \\ ${ }^{a}$ DIW Berlin, Mohrenstraße 58, 10117, Berlin, Germany \\ ${ }^{b}$ NRU HSE, Kantemirovskaya ul., 3, 194100, St. Petersburg, Russia
}

\begin{abstract}
As the institutional literature convincingly shows, socioeconomic phenomena are to a large extent shaped by the formal institutions, that is, legal acts (laws and ordinances). However, the latter are formulated in a specific language that is difficult to understand, let alone to measure. However, since the early 1990s, a whole branch of economic analysis of governmental regulations has evolved. It is known as leximetrics, i.e., the measuring of laws. It covers a wide range of economic sectors, such as financial, labor, housing, and product markets, among others. The two most popular methods are codification and surveys. Under the first method, the legal texts are analyzed, relevant provisions extracted, and numeric values assigned depending on these provisions. Under the surveys method, local experts are asked to provide their assessment of currently valid legal provisions and sometimes also their enforcement. In both cases, the legal texts are mapped onto real-valued indices with the objective of gauging the intensity of governmental regulations. These indices can be and are successfully used to explain the economic phenomena. This study provides a comprehensive overview of the leximetric literature and demonstrates interdependences between different types of governmental regulations.
\end{abstract}

Keywords: leximetrics; governmental regulations; economics.

JEL codes: C43, H24, K25, R38.

\footnotetext{
The authors confirm that the paper involves no interest conflicts.
} 


\section{Contents}

1 Introduction $\quad 1$

2 Methodology: Mapping laws to numbers 3

3 Application of leximetrics to economic research 5

3.1 Financial market / shareholder and creditor protection . . . . . . . . . 5

3.2 Labor market . . . . . . . . . . . . . . . . . . . . . . . . . 7

3.3 Housing market . . . . . . . . . . . . . . . . . . . . 8

3.4 Legal institutions . . . . . . . . . . . . . . . . . . . . . 9

3.5 Competition law . . . . . . . . . . . . . . . . . . . 10

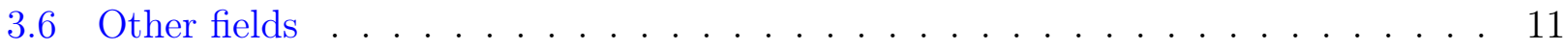

4 Quantitative analysis of regulation indices 12

$\begin{array}{llr}5 & \text { Conclusion } & 18\end{array}$

$\begin{array}{lr}\text { Literature } & 19\end{array}$

$\begin{array}{lr}\text { Appendix } & 26\end{array}$ 


\section{List of Figures}

1 Leximetric publications by year . . . . . . . . . . . . . . . . . . 2

2 Country and year coverage of regulation indices . . . . . . . . . . . . 13

3 Correlations of selected indicators . . . . . . . . . . . . . . . . . . 14

\section{List of Tables}

1 Estimation results of random-effects models . . . . . . . . . . . . . . . 17

1 Overview of leximetric studies . . . . . . . . . . . . . . . . . 26 


\section{Introduction}

Formal institutions, such as laws and ordinances, shape the framework conditions of economic agents and affect their incentives. Thus, it is important to be able to assess their impact on the economy because failing to not take them into account can lead to the omitted variable problem, biasing the estimation results. Therefore, it is necessary to measure the intensity and complexity of governmental regulations, e.g., by extracting the information contained in the texts of legal acts. The present study provides a comprehensive overview of the approaches suggested in the economic literature to solve this task. In addition, a statistical analysis of the related regulation indices is carried out.

Since the early 1990s, a new branch of literature, leximetrics, emerged. Its objective is to develop and apply the methodology of measuring the intensity of governmental regulations. The term "leximetrics" was apparently first introduced in this sense in 2003 by Robert Cooter and Thomas Ginsburg, whose objective was to explain why the specificity of laws varies from country to country, although the approach dates much farther back. Since the seminal study of Cooter and Ginsburg (2003), who acknowledged that leximetrics can be used for legal comparisons over time rather than merely across countries, a significant number of comparative law studies using leximetric tools have been published, as seen in Figure 1, which depicts the frequency of the leximetric publications. Accordingly, this technique is now an integral part of applied economic research.

Since the term "leximetrics" is not generally accepted, it makes it difficult to provide a realistic estimate of the number of publications using it as a tool. Therefore, this chart only represents a selection. This selection includes those studies mentioned in this text and the

journal articles from the Center for Business Research (CBR) "Law, Finance and Development" project. In addition, several papers were included that appeared when using the search term "leximetrics" in Google Scholar. The sample not only contains studies that introduce own leximetric approaches, but also those that use a leximetric index developed by someone else. It is far from comprehensive but gives a rough estimate on the extent of leximetric research. Overall, 122 leximetric studies are identified, peaking around the Great Recession of 2008-2009. In what follows, we will discuss the most relevant of the studies, focusing both on their topic and methodology. 
Figure 1: Leximetric publications by year

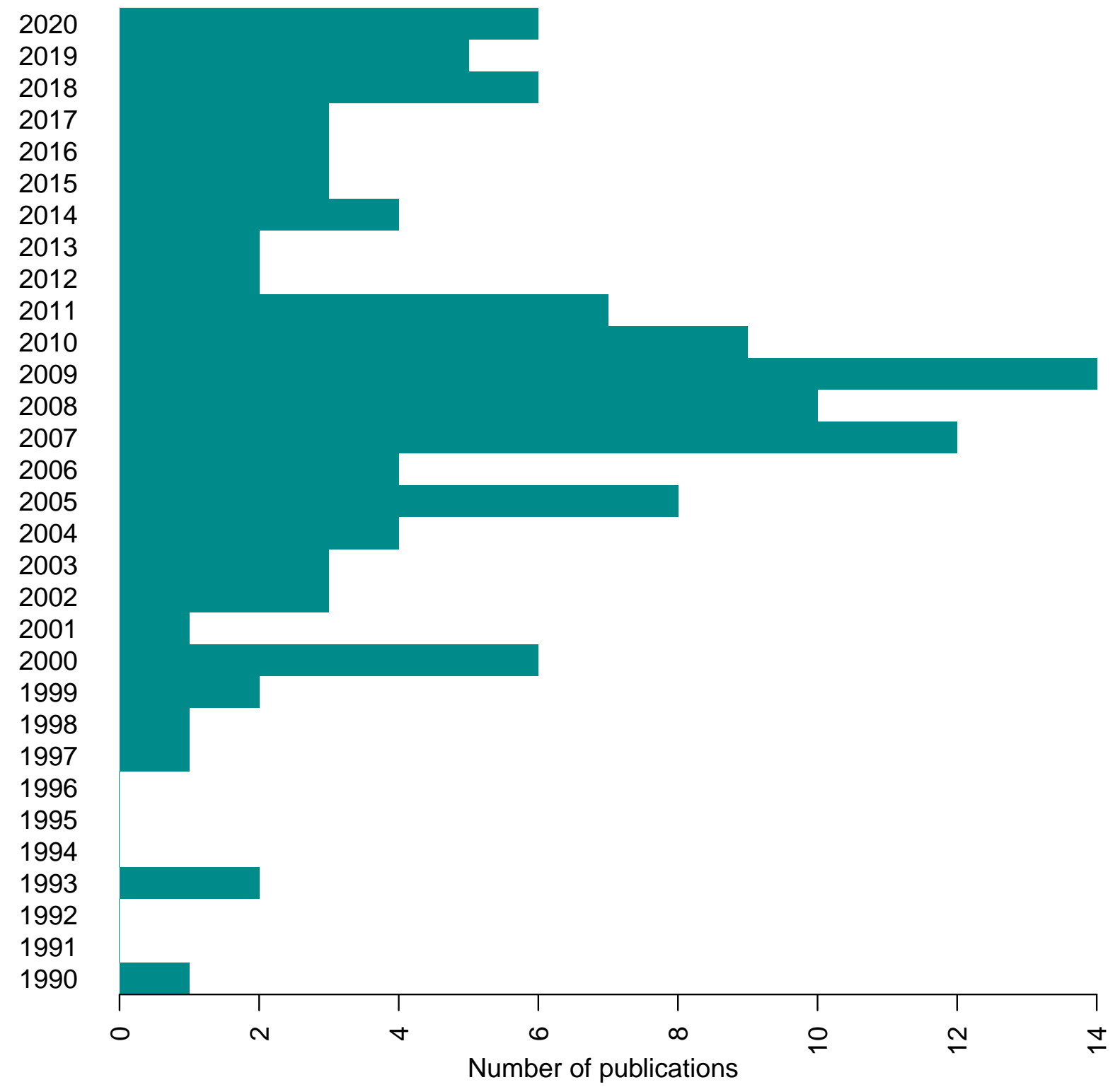


The paper is organized as follows. In section 2, we provide an overview of the methodology of measuring the governmental regulations. Section 3 presents the application of leximetric methodology to various sectors of the economy. In section 4, a quantitative analysis of different regulation indices is conducted. Finally, section 5 concludes.

\section{Methodology: Mapping laws to numbers}

It can appear extremely difficult to map the intricate legal texts to the real numbers. It is. However, the desire to measure the degree of intensity of regulations in order to conduct empirical studies of their effects on socioeconomic phenomena is stronger. Therefore, various methods are suggested to solve the measurability issue.

The two most popular methods are codification and surveys. Under the first method, the legal texts are analyzed by the researchers themselves, relevant provisions are extracted using a previously elaborated catalog of questions, and numeric values assigned depending on these provisions. Under the surveys method, the local experts (mostly governmental bodies or law firms) are asked to provide their assessment of currently valid relevant legal provisions and sometimes also of their enforcement. In both cases, the legal texts are mapped into real-valued indices with the objective of gauging the intensity of governmental regulations. There are also approaches that use a combination of surveys, the codification of laws, or other proxies (e.g., Malpezzi and Ball, 1993). Table 1 in Appendix provides an overview of the leximetric studies considered in this study and the kind of methodology they use. Each methodology has certain strengths and weaknesses. Survey-based data are possibly easier to work with than actual legal texts but they may not reflect the objectivity of the law as clearly, since they are subject to a certain bias of the consulted experts. However, on the positive side, the experts are supposed to know the legal situation in their country better than researchers, who approach it from outside. Gathering the relevant data can be challenging for both methods. Laws from some countries (not only developing ones) or older legal texts are usually difficult to obtain. Language barriers represent an additional difficulty, which is exacerbated even more in the case of older documents. For example, during the 20th century, the orthography of some languages changed (e.g., Estonian and Russian languages), while in China and Japan after WWII the characters were substantially simplified, meaning that even native speakers can no longer read the older 
texts. All these reduce the potential country and time series coverage for most indicators. For surveys, it can be difficult, if not impossible, to assess the legal situation in the past because of a lack of experts who are familiar with the situation of several decades ago, not to mention more than one generation ago.

Most studies considered in this paper use different approaches for coding their indicators. Certainly there is a trade-off between simplicity and feasibility (cf. Whitehead et al., 2012). Some studies only use binary coding, which seems natural since the existence or absence of a certain provision is most easily reflected by either 0 or 1 . Other studies rely on non-binary coding or use both. Lele and Siems (2007) acknowledge the fact that binary variables can be an oversimplified method, while non-binary variables can appear arbitrary or judgmental. Another challenge when coding legislation is the issue of weights. Most studies use a simple average of their subvariables in order to build the overall index. Using specific weights for certain variables can be rather judgemental but stating that all subvariables are equally important can be misleading too. Some studies try to account for this by using factor analysis or principal component analysis (e.g., Zaaruka et al., 2011).

Another difference is that some studies prefer to compare an overall index, while others compare each (sub)variable separately. Armour et al. (2009); Lele and Siems (2007) differentiate between functional convergence of different legislations by quantifying the differences of the merged aggregate index and formal convergence by quantifying the differences of each subvariable.

Leximetric studies have a number of issues that adversely affect their applicability. One issue related to leximetrics is that the impact of regulation is not always clear (cf. Whitehead et al., 2012). For example, when it comes to rent regulation, there are certain provisions that can benefit the tenant, while other can benefit landlords or even both of them. Furthermore, the same aggregate score of an index suggests that legislation in different countries is quite similar, when in fact the regulations can be very distinct. For instance, an index could attain the same value for two countries because one has a very strong regulation in one subindicator but no regulation for the other and vice versa. Analyzing the differences between subvariables brings up the question of institutional complementarities and substitution effects (cf. Armour et al., 2009). 
Another big issue is how to deal with law enforcement, e.g., when regulation gives the authority for deciding important matters to courts. Some studies try to implement the quality of enforcement (Malpezzi and Ball, 1993; Djankov et al., 2002a). International Labour Office (2015); Armour et al. (2009) acknowledge the fact that their data only reflect de jure law and not law applied in practice. However, their data can be combined with indicators, which reflect the effectiveness of legal institutions, for example, the Freedom House Indicator. Some studies solely reflect the law on the books (Forteza and Rama, 1999). This can be problematic, as illustrated by housing laws during apartheid in South Africa. The law on the books provided comprehensive tenure security but South Africa's black majority did not benefit from it. Fedderke et al. (2001) suggest a solution for this problem by creating an index that is based on the population distribution between racial groupings. Whether to include law enforcement or not ultimately depends on the scope of the research. Some might want to explicitly measure the law on the books and neglect law enforcement for various reasons. Interestingly, this problem can also be seen the other way around: Glaeser et al. (2004) measured institutional outcomes and highlighted the need to focus on actual measurement of law.

Some leximetric studies contradict each other in certain aspects. The studies related to the Legal Origins Theory and the leximetric studies by the Centre for Business Research (CBR) are good examples, since they mostly do not agree on the impact of legal origins. Whether their different findings are caused by different approaches, data, or methodology is not always clear. After all, it must be recognized that comparing regulations across countries is complex because regulations are difficult to analyze isolated from the wider regulatory environment of a country (cf. Nicoletti et al., 1999).

\section{Application of leximetrics to economic research}

Leximetrics is used in a large variety of areas, such as labor market, finance, shareholder protection, housing, and competition law. Below, we describe its application in each of these respective fields of research.

\subsection{Financial market / shareholder and creditor protection}

Probably the most influential work using leximetrics is that of La Porta et al. $(1998,1997)$. Some consider it to be the first use of leximetrics, even though other studies used the indexation 
of laws years earlier (Table 1). La Porta and coauthors analyze the strength of shareholder and creditor protection by codifying laws from 49 countries with a system of binary variables. In their methodology, they distinguish between the different legal origins - namely English, French, German, Scandinavian, and Socialist - and conclude that the stringency of investor protection differs substantially around the world. Common law countries seem to have a relatively high standard of shareholder protection, while civil law systems, especially those from French legal origin, seem to have a lower standard of shareholder protection. These findings led to the formulation of the legal origins theory (La Porta et al., 2008), which is complemented by Levine (1999) and Beck et al. (2002). It states that the legal origin shapes the lawmaking of a country and, therefore, its economic outcomes. The approach from La Porta et al. (1998) is used as a reference in many other studies. For example, subsequently Djankov et al. (2007), using the same methodology, expand the sample to 129 countries and 25 years of data, while Pistor (2000) followed a similar approach for several transition economies but put special emphasis on enforcement rather than the law on the books. Other authors, including Dyck and Zingales (2004); Licht et al. (2005); Pagano and Volpin (2005); Giofré (2013), use the same indices in their studies.

Other contributions to leximetrics, in general, and research on shareholder/creditor rights, specifically, derive from the project "Law, Finance and Development" by the Centre for Business Research at the University of Cambridge. The project features different data sets for creditor protection, shareholder protection, and labor regulation. Combined, these data sets underlie a huge body of work, including over 40 journal articles, over 30 working papers, several book chapters, and dozens of workshop/conference papers. Interestingly, some of their findings, in certain aspects, contradict the leximetric studies connected to the aforementioned legal origins theory. Not satisfied with the prior attempts of the quantification of shareholder protection laws, Lele and Siems (2007) sought to create a new more meaningful shareholder protection index consisting of 60 variables. By not only comparing the overall index but also quantifying the differences for each (sub)variable, the authors cannot distinguish between common-law and civil-law countries. Their findings show that shareholder protection across legal systems converges in an upward movement. Other papers that are based on the CBR data sets also arrive at similar conclusions (Armour et al., 2009; Siems, 2010; Katelouzou and Siems, 2015). 
There are also several leximetric approaches to measure financial reforms. Bandiera et al. (2000) and Laeven (2003) measure financial liberalization for a small set of countries along different dimensions, while Abiad et al. (2008) feature 91 countries over the 1973 to 2005 period. While Abiad et al. (2008) only provide a database, Bandiera et al. (2000) conclude that financial liberalization does not increase savings. Moreover, Laeven (2003) claims that it reduces financial constraints for small firms but increases them for large ones.

More recently, Bremus and Kliatskova (2020) examine how the institutional quality and institutional harmonization across Europe impact financial outcomes. Inspired by the approach of Kalemli-Ozcan et al. (2010), they created a bilateral financial harmonization index along 55 variables. The aggregate score reveals the financial harmonization of both countries. In addition, the authors used several indicators of institutional quality from the World Bank Doing Business reports.

\subsection{Labor market}

There are many leximetric studies analyzing labor market regulation, several using the data from the OECD Employment Outlook (Nicoletti et al., 1999; Howell, 2005), which focus on employment protection legislation (EPL), and partly follow the methodology of Grubb and Wells (1993). The OECD EPL data were mainly gathered through questionnaires answered by governments; however, this changed at some unknown point. Now the data are updated annually and sources include firm-level surveys and an increased number of statutory laws. Nicoletti et al. (1999), comparing product market legislation and EPL, find that these are closely related. Pagano and Volpin (2005), on the other hand, compare the same EPL index and the shareholder protection index of La Porta et al. (1998) and show a negative correlation between these two types of regulations. Nicoletti et al. (1999) admit that employment protection only reflects a portion of labor market regulation. This limited aspect is also examined earlier by Lazear (1990).

Forteza and Rama (1999) intend to measure the impact of labor market policies on the success of economic reforms. They use a database from the World Bank (Rama and Artecona, 2000) to gauge the extent of labor market rigidity. In addition, they use the number of International Labour Organization (ILO) conventions ratified by a country as a proxy for labor rigidity on paper along with other indicators, such as minimum wages. 
Botero et al. (2004) examine employment law, industrial and collective relations law, as well as social security law in 85 countries. A standardized worker was considered in order to ensure that the results from different countries are comparable. Their findings are consistent with the legal origins theory and suggest that richer countries have a lower level of labor regulation but a higher level of social security in return when compared to poorer countries. The data correlate with other indices concerning procedural formalism (Djankov et al., 2002a) and the regulation of entry (Djankov et al., 2002b).

The CBR research on labor regulation also lead to several leximetric studies. Deakin et al. (2007) examine the evolution of labor law using 40 variables. Their categories for coding are similar to Botero et al. (2004) but pay attention to collective agreements, while ignoring social security laws, since it is very distinct from labor law, according to the authors. They recognize

a distinction between common and civil law countries on the aggregate level but challenge the legal origins theory based on their findings on the lower level. Other CBR studies using the same index but for different sets of countries include Armour et al. (2009); Deakin et al. (2014); Adams et al. (2015).

In 2015, the International Labour Organization published a study that uses an extended CBR data set to document the evolution of labor regulation over time. The ILO claims that the effect of employment protection legislation on the level of unemployment is very limited and can be positive or negative.

\subsection{Housing market}

The first attempt to compare housing legislation with the help of leximetrics was made by Malpezzi and Ball (1993). Using nine different elements, they create a preliminary rent control index that aims to assess the overall stringency of rent control within a country. Regarding the overall index as an exploratory one, the authors acknowledge the rough and judgmental, perhaps even arbitrary, nature of such an index.

Another rather different approach to compare housing laws with the use of quantitative methodology is made by Djankov et al. (2002a). They try to show the level of procedural formalism by measuring the procedures that are necessary to evict a tenant. As one of the only indices that reflects the enforcement of tenancy and rental laws, the procedural formalism index is also used in other studies (Cuerpo et al., 2014; Weber, 2017). 
Andrews et al. (2011) use an OECD Housing Market questionnaire to gauge the degree of rent control and protection for tenants by creating two distinct indices. Cuerpo et al. (2014) use similar methodology but expande the sample and also incorporate country-specific legal documents. They also prefer to analyze their subindices separately rather than a merged overall index for rent control, a view that is shared by Whitehead et al. (2012). The Global Property Guide's landlord and tenant rating system ${ }^{1}$ distinguishes a country's legislation as either (strongly) pro-tenant, pro-landlord, or neutral using 17 questions concerning the rent setting, deposits provisions, duration of contract/eviction, and the effectiveness of the legal system. Thus, GPG also intends to approximate the degree of enforcement. A big disadvantage of the data, though, is that it is not clear how up-to-date are the assessments of regulations. In some cases, it appears that the currently indicated assessment was actually carried out at least a decade ago, thus, no longer reflecting the actual, current, situation

Miletić (2016) is among the first to use leximetric methodology to analyze the evolution of housing regulation over time within certain countries. Thus, he constructs a longitudinal database instead of a cross-section one, as carried out in previous studies. Focusing on the housing situation during World War I, he uses a system of six discrete stages to measure rent control in Eastern Europe from 1914 through 1928. Kholodilin (2017) and Weber (2017) contributed to the leximetric research in the housing field by introducing the time dimension as well. Their approach employs binary variables to measure rental regulation across countries and time. Using and extending the approach of Weber, Kholodilin (2020) covers 101 countries or subnational regions for a period between 1910 and 2020.

Beyond the above mentioned housing regulation studies, Atterhög (2005) focuses on home ownership policies. Based on surveys conducted in 18 countries, he builds six indices (direct grants for buying, other subsidies, mortgage deduction, grant tax deduction, low property tax, and homeownership allowances) covering 1970 to 2000 at a decade frequency.

\subsection{Legal institutions}

There are also several leximetric studies focusing on the measurement of legal or political institutions in order to estimate their potential impact on economic processes. Glaeser et al.

\footnotetext{
${ }^{1}$ See https://www.globalpropertyguide.com/landlord-and-tenant.
} 
(2004) use different measures for the quality of institutions, e.g., an executive constraints variable from Jaggers and Marshal (2000), an expropriation risk variable from the International Country Risk Guide, and a government effectiveness variable from Kaufmann et al. (2003), in order gauge their impact on the growth. Although not all of their variables measure the strength of laws directly, more or less they are connected to the strength of legal conditions. The authors highlight the need for actual measurement of laws over ambiguous assessments of institutional outcomes.

Zaaruka et al. (2011) measure institutions in Namibia from 1884 through 2008. They employ several leximetric indicators, e.g., for property rights, political rights, civil liberties, and judicial independence, which correlate with other institution measures, like the Freedom in the World Index.

Other measures for institutions include the World Justice Project Rule of Law Index (Botero and Ponce, 2011) and the Freedom in the World Index by Freedom House (Freedom House, 2020). Both indices are published annually and rely on expert judgements and surveys. They do not directly measure certain laws but ultimately quantify legislation and law enforcement to a certain extent.

\subsection{Competition law}

There are also a number of studies focusing on the measurement and comparison of competition law across different jurisdictions.

Nicholson (2008) compare competition law across 52 jurisdictions with the Antitrust Law Index. Hylton and Deng (2007) build on this approach to cover 102 countries and additionally introduced a time series dimension that covers the period from 2001 to 2004 period. Buccirossi et al. (2011) constructed several indices that gauge the degree of competition policy in 13 countries over a time-span from 1995 to 2005. Bradford et al. (2019) introduced two data sets for competition law: one focusing on law and another concentrating on enforcement. With data from 131 jurisdictions covering over 100 years, they present the most comprehensive approach to measure competition law.

Other approaches to measure competition law mostly reflect the situation of one specific year (Borrell and Jimenez, 2008; Voigt, 2009; Alemani et al., 2016). Voigt (2009) and Alemani 
et al. (2016) build their indicators based on surveys, while the other indicators are constructed through the codification of laws.

\subsection{Other fields}

Despite the extensive research in the economic sectors discussed above, other fields receive substantially less attention. The literature in each of the following fields is too scarce to be discussed in separate sections. Therefore, we discuss them under the same heading.

Regulation of entry: Djankov et al. (2002b) measure the requirements to start a business in 85 countries. By analyzing the number of procedures, the cost of entry, and the time that is necessary to complete the process, they find that a high standard of entry regulation does not correlate with better quality of public or private goods.

Product market regulation: Nicoletti and Scarpetta (2003) create an index for product market regulation in 18 OECD countries. Four sets of indicators are used, namely economywide regulation, industry-level regulation, regulatory reform, and privatization. The authors claim that heavy regulation harms productivity and technological development.

Extent of legislation: Similar to Cooter and Ginsburg (2003), Mulligan and Shleifer (2005) measure the extent of regulation. Instead of the number of words in a legal document, they use the size of files as a metric. Their data show that jurisdictions with larger populations regulate more. They also show this by comparing other leximetric indices, e.g., regulation of entry by Djankov et al. (2002b) and employment law by Botero et al. (2004).

Debt enforcement: Djankov et al. (2008) measure the efficiency of debt enforcement. They use an imaginary standardized hotel to compare the procedures across different countries. By quantifying the time and disposition of assets, they create an index that correlates with percapita income and legal origins.

Property rights: Djankov et al. (2020) build an indicator showing the strength of property rights in the main business city of 190 countries. This indicator is called a transfer of title indicator summarizing the number of procedures, cost, and time.

Social objectives: Hartlapp (2020) build an indicator that aims to measure the social objectives of a certain policy. The overall index comprises substance, potential impact, and enforcement. The substance is gauged by dividing the number of standards found by the number of possible standards. Potential impact and enforcement are variables that function as 
multipliers. The author uses this methodology to compare public procurement regulations in France and Germany.

Sustainable development goals: The Sustainable Development Goals passed by the United Nations in 2015 (United Nations Statistical Office, 2017) include several indicators that aim to measure the intensity or compliance of certain laws and provisions. In this way, leximetrics can be utilized to measure the progress towards more sustainable development. The methodology underlying some of these indicators to measure laws is still a work in progress.

Modern tax system: Seelkopf et al. (2021) measure the advent of the modern tax system by indicating the year of introduction of each of the six key modern taxes (personal income tax, corporate income tax, social security contributions, inheritance tax, general sales tax, and value added tax) in 220 countries between 1750 and 2018.

\section{Quantitative analysis of regulation indices}

In this section, we examine the spatio-temporal coverage of regulation indices discussed above as well as the relationships between them. Overall, we collected information on 51 governmental regulation indices from various studies. The country and year coverage of these indices is very different, as seen in Figure 2. The horizontal axis corresponds to the number of countries and the vertical axis corresponds to the number of years for which each index is available. The colors denote sectors or fields to which each index can be classified; see Table 1.

The data availability varies from 5 to 200 countries and from 1 to 112 years. Among 51 indices, 19 represent cross-sections, while the rest are panel data. Most indices are rather shortterm since they cover less than 60 years. The country coverage is much better, with $47 \%$ of indices covering more than 40 countries.

The governmental regulations adopted in different fields are often interdependent. They address related challenges and reflect the general strategy of the ruling cabinet (e.g., leftist or liberal). Therefore, it is important to see how correlated the various regulation indices are. The computation of correlations is not always possible because the country-year coverages sometimes do not intersect or leave too few common observations. Therefore, the correlations are computed only for indicators that cover at least 25 countries and 20 years. Figure 3 shows a correlation matrix that includes the selected indicators. 
Figure 2: Country and year coverage of regulation indices

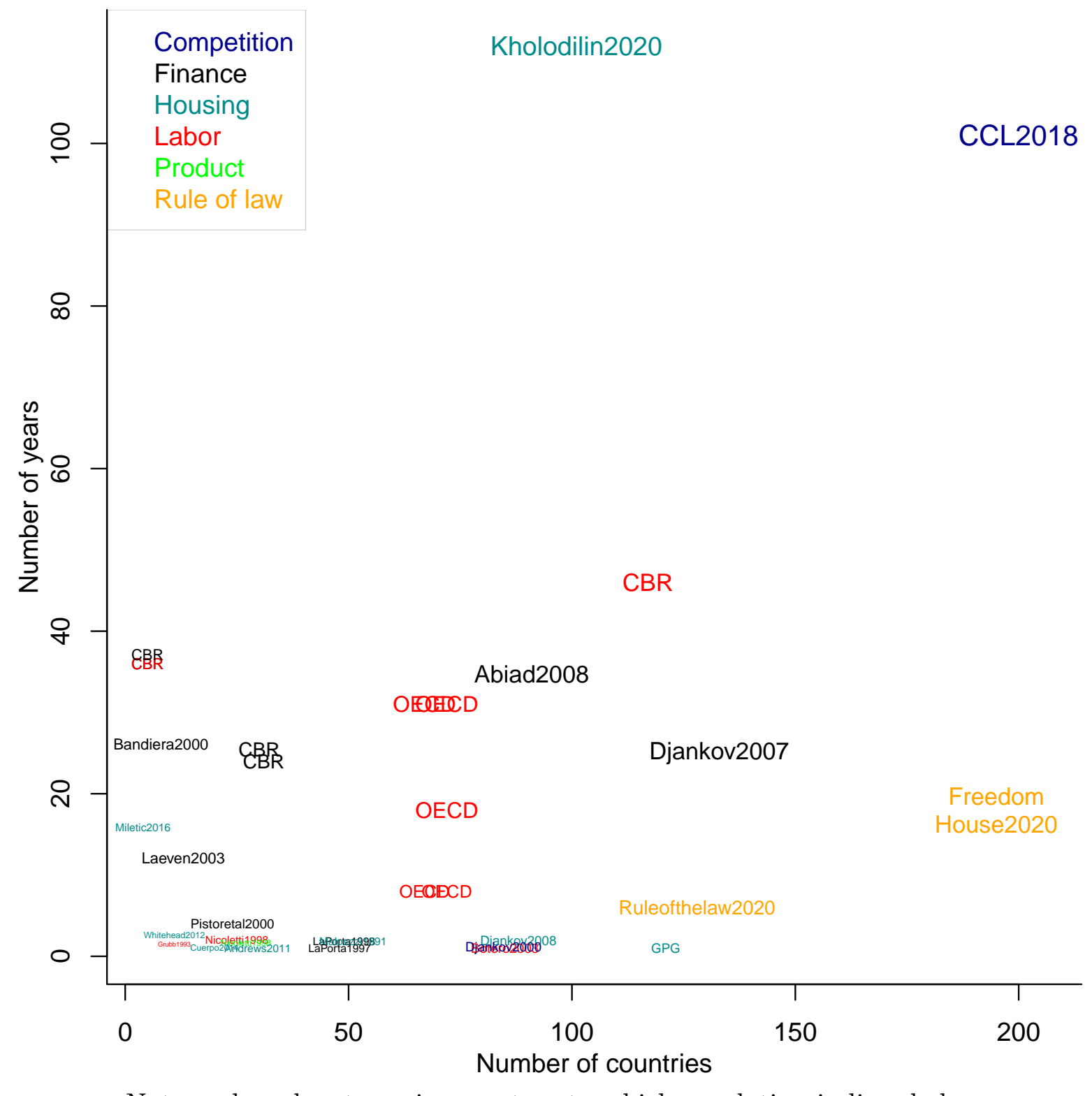

Note: colors denote various sectors to which regulation indices belong. 
Figure 3: Correlations of selected indicators

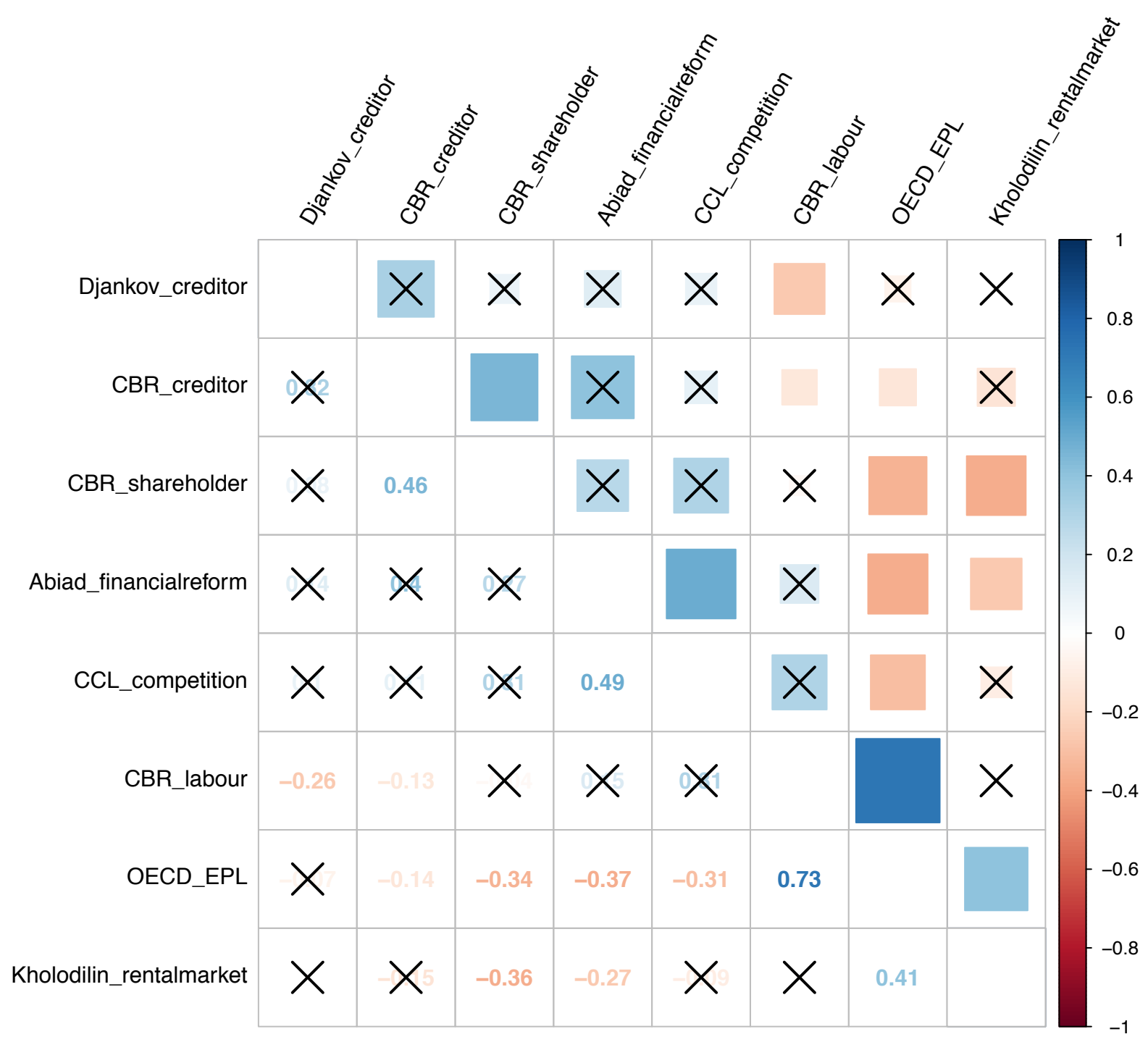

Note: Blue colored boxes denote positive correlations, while the red colored boxes indicate negative correlations. The larger the box, the higher the absolute value of the corresponding correlation coefficient. Correlations that are not significant at the 0.1 level are crossed out. Sources: Abiad et al. (2008), Armour et al. (2016), Bradford et al. (2019), Djankov et al. (2007), Kholodilin (2020), and OECD.Stat. 
Positive and negative correlations can be observed, thus, showing that strong legislation in one field does not always imply strong legislation in other fields. There are many correlations that are not statistically significant. Not surprisingly indicators that aim to measure similar kinds of legislation, such as the OECD Employment Protection Legislation Index and the CBR Labour Regulation Index of Adams et al. (2016), have a strong positive correlation. The same thing goes for the Financial Liberalization Index of Abiad et al. (2008) and the CCL Competition Law Index of Bradford et al. (2019). On the other hand, there are negative correlations between the OECD EPL Index and creditor, shareholder, financial reform, and competition law indices. Rental market regulation seems to correlate negatively with shareholder protection and financial reform. Generally, these findings suggest that there is indeed a divergence between different fields of regulation. Generally speaking, financial law indicators correlate positively with each other, but they correlate negatively with labor or housing regulations.

Finally, we examine the factors that determine various regulations considered here using the following random-effects panel data model:

$$
y_{i t}=\mu+\sum_{k=1}^{K} \beta_{k} x_{i t}^{k}+u_{i}+v_{t}+\varepsilon_{i t}
$$

where $y_{i t}$ is a corresponding regulation index in country $i$ in year $t ; \mu$ is the intercept; $x_{i t}^{k}$ is an explanatory variable $k ; u_{i}$ and $v_{t}$ are the country and year random effects; $\varepsilon_{i t}$ is the random disturbance. The random-effects model is needed because we employ the variable of legal origin, which is constant over time.

Table 1 reports the estimation results of the random-effects panel data models for eight leximetric indicators regressed on a set of conventional control variables. These include a lag of GDP per capita in 1000 constant 2011 purchasing power parity dollars, ${ }^{2}$ annual war deaths per 1000 persons as a proxy for war intensity, ${ }^{3}$ dummy variables for legal origins (with the English legal origin as the reference) ${ }^{4}$ and a dummy variable for left governments as independent

\footnotetext{
${ }^{2}$ Data from GAPMINDER: GDP per capita v25 — constant PPP\$ 2011 based on World Bank, Maddison, and IMF, see: https://www.gapminder.org/gdp-per-capita/.

${ }^{3}$ The data on the number of war deaths in inter- and intra-state wars are taken the from Correlates of War (COW) Project version 4.0 (https://correlatesofwar.org/) and divided by the population size to make them comparable across space and time.

${ }^{4}$ The classification follows Djankov et al. (2007).
} 
variables. ${ }^{5}$ For each indicator, two alternative models are estimated: one with and one without the left government dummy, since this variable is available for a much more limited sample. The per-capita GDP should serve as a proxy for the level of economic development; the war deaths measure the intensity of military conflicts, which often spur governmental regulations; the legal origins indicator reflects the legal tradition in each country and, thus, can affect the readiness for the government to intervene; while the left government dummy can be a reflection of supportiveness of the society for more paternalist policies.

\footnotetext{
${ }^{5}$ Data from Scheve and Stasavage (2009). The dummy is defined as follows: 1, if the country had a prime minister and/or president from a left party, and 0, otherwise. We extended the original index to include the years after 2000, when it ends, and additional countries, such as Austria, Belgium, Denmark, Finland, Italy, Norway, and Portugal.
} 


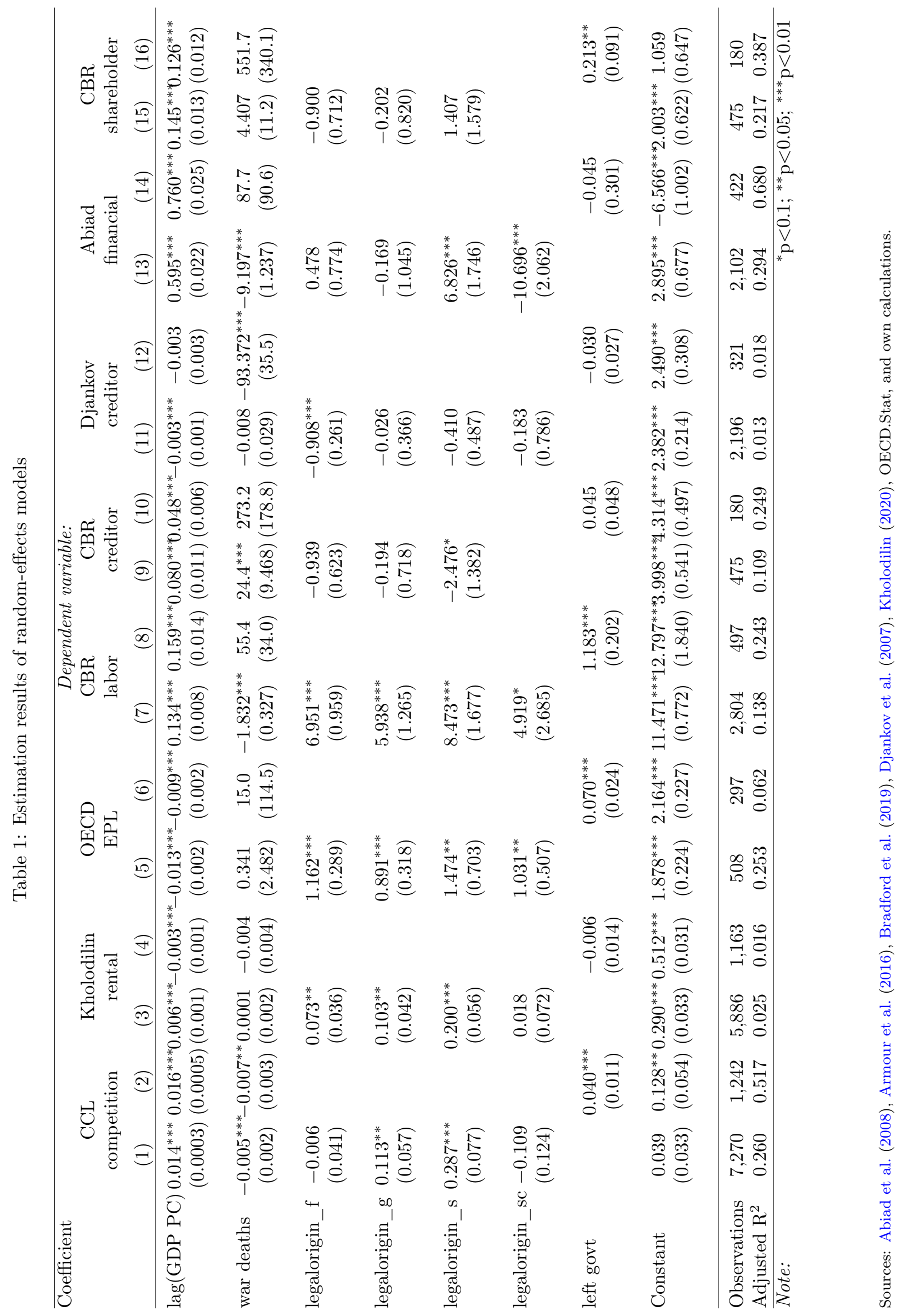


GDP per capita seems to be statistically significantly associated with strong competition laws, shareholder protection, and financial liberalization. The impact on labor laws and creditor protection is ambiguous for the considered indicators. In times of war, competition law and financial liberalization seem to be significantly lower. This is probably related to war-time dirigism, when the society and economy are subjected to strict controls in order to mobilize the maximum of resources that would allow to win. The extent of regulation differs substantially across legal origins. These findings are widely consistent with Botero et al. (2004), who show that countries with a common law system, i.e., with English legal origin, tend to have a lower regulation of labor, while left governments are associated with stronger regulation of labor. Botero et al. (2004) claim that employment protection is weaker in richer countries. The results for the OECD employment protection legislation index seem to support this argument. On the other hand, they also show that this is not the case for industrial regulation law, which could explain why GDP per capita positively affects the CBR labor regulation index, which takes industrial action and employee representation into account.

These analyses are more of an exploratory nature and their explanatory power is limited. Many other variables that possibly could affect lawmaking are not taken into account due to the lack of data. Nevertheless, it gives some interesting insights on how different types of regulation are related to each other and what could determine the strength of these laws.

\section{Conclusion}

When comparing different leximetric studies, the first thing that stands out is the variety of different approaches. These differences can be observed along various dimensions. Obviously, there are the differences in the field of study. Since regulations comprise many aspects of life and society, the impact of all these regulations can be assessed leximetrically. So far, most studies concentrate on finance, specifically creditor and shareholder protection, as well as regulation of labor. Other areas of leximetric research include housing regulation and competition law. However, this is just a small part of the bigger picture as the perspectives for leximetric research seem endless.

Another dimension separating these studies from each other is how they gather their data. Most researchers rely on the actual laws, while others use surveys. There are also studies 
that take advantage of expert judgments - in most cases, law firms - or use data based on other studies or reports by different institutions. All these different methods share the same problem because they are all subject to a certain level of bias. While the law itself is objective, the way researchers codify it in order to construct variables or indices can differ substantially. Surveys provide objective data, but the construction of questionnaires is subjective. Relying on experts and other studies or reports always reflects the interpretation of these experts. The way researchers process data in order to construct their variables and indices can be rather distinct, although binary variables are most common. Working with these variables differs in most studies concerning the aggregation methods and weights. The possibilities of working with leximetric data are endless and there is no standard to which researchers can agree upon at the moment.

Researchers must be aware of these issues when dealing with leximetrics. It is important that the data sources and construction methods are available to the public and described understandably, so that scholars can learn from each other. In order to use leximetrics to its fullest potential and excel in this field, researchers should come together, compare their findings, and develop standards for the further utilization of this powerful tool.

\section{Literature}

Abiad, A., E. Detragiache, and T. Tressel (2008). A new database of financial reforms, Volume 2266. International Monetary Fund.

Adams, Z., L. Bishop, and S. Deakin (2016). CBR Labour Regulation Index (dataset of 117 countries). Cambridge: Centre for Business Research.

Adams, Z., L. Bishop, S. Deakin, C. Fenwick, S. Martinsson, and G. Rusconi (2015). Labour regulation over time: new leximetric evidence. In 4th Conference of the Regulating for Decent Work Network, Developing and Implementing Policies for a Better Future for Work. ILO, Geneva.

Alemani, E., C. Klein, I. Koske, C. Vitale, and I. Wanner (2016). New indicators of competition law and policy in 2013 for oecd and non-oecd countries. In Competition law enforcement in the BRICS and in developing countries, pp. 59-102. Springer, Cham. 
Andrews, D., A. Caldera Sánchez, and A. Johansson (2011). Housing markets and structural policies in OECD countries. OECD Economic Department Working Papers.

Armour, J., S. Deakin, P. Lele, and M. Siems (2009). How do legal rules evolve? evidence from a crosscountry comparison of shareholder, creditor, and worker protection. The American journal of comparative law 57(3), 579-630.

Armour, J., S. Deakin, P. Sarkar, M. Siems, and A. Singh (2009). Shareholder protection and stock market development: an empirical test of the legal origins hypothesis. Journal of Empirical Legal Studies 6(2), 343-380.

Armour, J., S. Deakin, and M. Siems (2016). CBR Leximetric Datasets. https://doi.org/10.17863/CAM.506.

Atterhög, M. (2005). The effect of competition and ownership policies on the housing market. Ph. D. thesis, KTH.

Bandiera, O., G. Caprio, P. Honohan, and F. Schiantarelli (2000). Does financial reform raise or reduce saving? Review of economics and statistics 82(2), 239-263.

Beck, T., R. Levine, and A. Demirgüç-Kunt (2002). Law and finance: why does legal origin matter? The World Bank.

Borrell, J. R. and J. L. Jimenez (2008). The drivers of antitrust effectiveness. Hacienda Pública Española / Revista de Economía Pública 185(2), 69-88.

Botero, J. C., S. Djankov, R. La Porta, F. Lopez de Silanes, and A. Shleifer (2004). The regulation of labor. The Quarterly Journal of Economics 119(4), 1339-1382.

Botero, J. C. and A. Ponce (2011). Measuring the Rule of Law. The World Justice Project Working Paper Series.

Bradford, A., A. S. Chilton, C. Megaw, and N. Sokol (2019). Competition law gone global: introducing the comparative competition law and enforcement datasets. Journal of Empirical Legal Studies 16(2), 411-443. 
Bremus, F. and T. Kliatskova (2020). Legal harmonization, institutional quality, and countries' external positions: A sectoral analysis. Journal of International Money and Finance 10\%, $* * *$.

Buccirossi, P., L. Ciari, T. Duso, G. Spagnolo, and C. Vitale (2011). Measuring the deterrence properties of competition policy: The competition policy indexes. Journal of Competition Law and Economics 7(1), 165--204.

Cooter, R. D. and T. Ginsburg (2003). Leximetrics: Why the same laws are longer in some countries than others. University of Illinois Law and Economics Research Paper No. LE03012.

Cuerpo, C., S. Kalantaryan, and P. Pontuch (2014). Rental market regulation in the European Union. European Economy - Economic Papers 515.

Deakin, S., P. Lele, and M. Siems (2007). The evolution of labour law: Calibrating and comparing regulatory regimes. International Labour Review 146(3-4), 133-162.

Deakin, S., J. Malmberg, and P. Sarkar (2014). Do labour laws increase equality at the expense of higher unemployment? the experience of six OECD countries, 1970-2010. University of Cambridge Faculty of Law Research Paper No. 11/2014.

Djankov, S., E. L. Glaeser, V. Perotti, and A. Shleifer (2020). Measuring property rights institutions. National Bureau of Economic Research. No. w27839.

Djankov, S., O. Hart, C. McLiesh, and A. Shleifer (2008). Debt enforcement around the world. Journal of Political Economy 116(6), 1105-1149.

Djankov, S., R. La Porta, F. Lopez de Silanes, and A. Shleifer (2002a). Courts: the lex mundi project. National Bureau of Economic Research. No. w8890.

Djankov, S., R. La Porta, F. Lopez de Silanes, and A. Shleifer (2002b). The regulation of entry. The Quarterly Journal of Economics 117(1), 1-37.

Djankov, S., C. McLiesh, and A. Shleifer (2007). Private credit in 129 countries. Journal of Financial Economics 84(2), 299-329. 
Dyck, A. and L. Zingales (2004). Private benefits of control: An international comparison. The Journal of Finance 59(2), 537-600.

Fedderke, J. W., R. H. de Kadt, and J. M. Luiz (2001). Indicators of political liberty, property rights and political instability in South Africa: 1935-97. International Review of Law and Economics 21(1), 103-134.

Forteza, A. and M. Rama (1999). Labor market "rigidity" and the success of economic reforms across more than 100 countries. The Journal of Policy Reform 9(1), 75-105.

Freedom House (2020). Freedom in the World 2020. https://freedomhouse.org/.

Giofré, M. (2013). Investor protection rights and foreign investment. Journal of comparative economics $41(2), 506-526$.

Glaeser, E. L., R. La Porta, F. Lopez de Silanes, and A. Shleifer (2004). Do institutions cause growth? Journal of economic growth 9(3), 271-303.

Grubb, D. and W. Wells (1993). Employment regulation and patterns of work in EC countries. OECD Economic studies 21, 7-58.

Hartlapp, M. (2020). Measuring and comparing the regulatory welfare state: Social objectives in public procurement. The ANNALS of the American Academy of Political and Social Science 691(1), 68-83.

Howell, D. (2005). Fighting unemployment: why labor market "reforms" are not the answer. Den Tredje Arbetslingen (The third work principle). Stockholm, Sweden: Arenagroup.

Hylton, K. N. and F. Deng (2007). Antitrust around the world: An empirical analysis of the scope of competition laws and their effects. Antitrust Law Journal 74 (2), 271-341.

International Labour Office (2015). World employment social outlook: The changing nature of jobs. ILO Research Department.

Jaggers, K. and M. G. Marshal (2000). Polity iv project: Political regime characteristics and transitions, 1800-1999. Unpublished manuscript, University of Maryland, Center for International Development and Conflict Management. 
Kalemli-Ozcan, S., E. Papaioannou, and J.-L. Peydró (2010). What lies beneath the euro's effect on financial integration? Currency risk, legal harmonization, or trade? Journal of international economics 81(1), 75-88.

Katelouzou, D. and M. Siems (2015). Disappearing paradigms in shareholder protection: Leximetric evidence for 30 countries, 1990-2013. Journal of corporate law studies 15(1), 127-160.

Kaufmann, D., A. Kraay, and M. Mastruzzi (2003). Governance matters iii: Governance indicators for 1996-2002. The World Bank.

Kholodilin, K. (2017). Quantifying a century of state intervention in rental housing in Germany. Urban research and practice 10(3), 267-328.

Kholodilin, K. A. (2020). Long-term, multi-country perspective on rental market regulations. Housing Policy Debate 30(6), 994-1015.

La Porta, R., F. Lopez de Silanes, and A. Shleifer (2008). The economic consequences of legal origins. Journal of economic literature 46(2), 285-332.

La Porta, R., F. Lopez de Silanes, A. Shleifer, and R. W. Vishny (1997). Legal determinants of external finance. The journal of finance 52(3), 1131-1150.

La Porta, R., F. Lopez de Silanes, A. Shleifer, and R. W. Vishny (1998). Law and finance. Journal of political economy 106(6), 1113-1155.

Laeven, L. (2003). Does financial liberalization reduce financing constraints? Financial management 32(1), 5-34.

Lazear, E. P. (1990). Job security provisions and employment. The Quarterly Journal of Economics 105(3), 699-726.

Lele, P. P. and M. M. Siems (2007). Shareholder protection: a leximetric approach. Journal of corporate law studies 7(1), 17-50.

Levine, R. (1999). Law, finance, and economic growth. Journal of financial intermediation 8(12), 8-35. 
Licht, A. N., C. Goldschmidt, and S. H. Schwartz (2005). Culture, law, and corporate governance. International review of law and economics 25(2), 229-255.

Malpezzi, S. and G. Ball (1993). Measuring the urban policy environment: an exploratory analysis using rent controls. Habitat international 17(2), 39-52.

Miletić, A. R. (2016). Tenancy vs. ownership rights. housing rent control in Southeast and East-Central Europe, 1918-1928. Mesto a dejiny 5(1), 51-74.

Mulligan, C. B. and A. Shleifer (2005). The extent of the market and the supply of regulation. The Quarterly journal of economics 120(4), 1445-1473.

Nicholson, M. W. (2008). An antitrust law index for empirical analysis of international competition policy. Journal of Competition Law and Economics 4(4), 1009--1029.

Nicoletti, G. and S. Scarpetta (2003). Regulation, productivity and growth: OECD evidence. Economic policy 18(36), 9-72.

Nicoletti, G., S. Scarpetta, and O. Boylaud (1999). Summary indicators of product market regulation with an extension to employment protection legislation. OECD, ECO Working Paper.

Pagano, M. and P. F. Volpin (2005). The political economy of corporate governance. American economic review 95(4), 1005-1030.

Pistor, K. (2000). Patterns of legal change: shareholder and creditor rights in transition economies. European business organization law review 1(1), 59-107.

Pistor, K., M. Raiser, and S. Gelfer (2000). Law and finance in transition economies. Economics of transition 8(2), 325-368.

Rama, M. and R. Artecona (2000). A database of labor market indicators across countries. Washington, DC, The World Bank.

Scheve, K. and D. Stasavage (2009). Institutions, partisanship, and inequality in the long run. World Politics 61(2), 215-253. 
Seelkopf, L., M. Bubek, E. Eihmanis, J. Ganderson, J. Limberg, Y. Mnaili, P. Zuluaga, and P. Genschel (2021). The rise of modern taxation: A new comprehensive dataset of tax introductions worldwide. The Review of International Organizations 16, 239-263.

Siems, M. M. (2010). The web of creditor and shareholder protection in 25 countries: A comparative legal network analysis. Arizona journal of international and comparative law 27 , 747.

United Nations Statistical Office (2017). Global indicator framework for the sustainable development goals and targets of the 2030 agenda for sustainable development. UN Resolution A (pp. 1-21). RES/71/313.

Voigt, S. (2009). The effects of competition policy on development-cross-country evidence using four new indicators. Journal of Development Studies 45(8), 1225-1248.

Weber, J. P. (2017). The regulation of private tenancies - a multi-country analysis. PhD Dissertation: Universität Regensburg, Faculty of Business, Economics and Management Information Systems Department of Economics.

Whitehead, C., S. Monk, K. Scanlon, S. Markkanen, and C. Tang (2012). The private rented sector in the new century - a comparative approach. Copenhagen: Boligokonimisk Videncenter.

Zaaruka, B., J. Fedderke, et al. (2011). Measuring institutions: Indicators of political and economic institutions in Namibia: 1884-2008. Working Papers 236, Economic Research Southern Africa. 


\section{Appendix}

Table 1: Overview of leximetric studies

\begin{tabular}{|c|c|c|c|c|}
\hline Study and indicator(s) & Field & Countries & $\begin{array}{l}\text { Time- } \\
\text { span }\end{array}$ & $\begin{array}{l}\text { Construction } \\
\text { method }\end{array}$ \\
\hline $\begin{array}{l}\text { La Porta et al. (1997), creditor } \\
\text { rights and antidirector rights in- } \\
\text { dex }\end{array}$ & Finance & 49 & $\begin{array}{l}\text { ca. } \\
1997\end{array}$ & Codification of laws \\
\hline $\begin{array}{l}\text { La Porta et al. (1998), creditor } \\
\text { rights and antidirector rights in- } \\
\text { dex }\end{array}$ & Finance & 49 & $\begin{array}{l}\text { ca. } \\
1998\end{array}$ & Codification of laws \\
\hline $\begin{array}{l}\text { Levine (1999), } 4 \text { indices for cred- } \\
\text { itor rights }\end{array}$ & Finance & 47 & $\begin{array}{l}1980- \\
1989\end{array}$ & Codification of laws \\
\hline $\begin{array}{l}\text { Pistor (2000), } 6 \text { aggregate indices } \\
\text { for shareholder protection }\end{array}$ & Finance & 24 & $\begin{array}{l}1992- \\
1998\end{array}$ & Codification of laws \\
\hline $\begin{array}{l}\text { Pistor et al. (2000), } 6 \text { aggregate } \\
\text { indices for shareholder protection }\end{array}$ & Finance & 26 & $\begin{array}{l}1992- \\
1998\end{array}$ & Codification of laws \\
\hline $\begin{array}{l}\text { Dyck and Zingales (2004), indices } \\
\text { from La Porta et al. (1998) }\end{array}$ & Finance & 49 & $\begin{array}{l}\text { ca. } \\
1998\end{array}$ & Codification of laws \\
\hline $\begin{array}{l}\text { Licht et al. (2005), indices from } \\
\text { La Porta et al. (1998) }\end{array}$ & Finance & 49 & $\begin{array}{l}\text { ca. } \\
1998\end{array}$ & Codification of laws \\
\hline $\begin{array}{l}\text { Pagano and Volpin (2005), share- } \\
\text { holder protection index from La } \\
\text { Porta et al. (1998) }\end{array}$ & Finance & 49 & $\begin{array}{l}\text { ca. } \\
1998\end{array}$ & Codification of laws \\
\hline $\begin{array}{l}\text { Djankov et al. (2007), creditor } \\
\text { rights index following La Porta } \\
\text { et al. (1998) }\end{array}$ & Finance & 129 & $\begin{array}{l}1978- \\
2003\end{array}$ & Codification of laws \\
\hline $\begin{array}{l}\text { Lele and Siems (2007), CBR } \\
\text { shareholder protection index }\end{array}$ & Finance & 5 & $\begin{array}{l}1970- \\
2005\end{array}$ & Codification of laws \\
\hline
\end{tabular}




\begin{tabular}{|c|c|c|c|c|}
\hline Study and indicator(s) & Field & Countries & $\begin{array}{l}\text { Time- } \\
\text { span }\end{array}$ & $\begin{array}{l}\text { Construction } \\
\text { method }\end{array}$ \\
\hline $\begin{array}{l}\text { Armour et al. (2009), CBR share- } \\
\text { holder protection index }\end{array}$ & Finance & 20 & $\begin{array}{l}1995- \\
2005\end{array}$ & Codification of laws \\
\hline $\begin{array}{l}\text { Siems (2010), CBR creditor and } \\
\text { shareholder protection index }\end{array}$ & Finance & 25 & $\begin{array}{l}1995- \\
2005\end{array}$ & Codification of laws \\
\hline $\begin{array}{l}\text { Giofré (2013), indices from La } \\
\text { Porta et al. (1998) }\end{array}$ & Finance & 49 & $\begin{array}{l}\text { ca. } \\
1998\end{array}$ & Codification of laws \\
\hline $\begin{array}{l}\text { Katelouzou and Siems (2015), } \\
\text { CBR shareholder protection in- } \\
\text { dex }\end{array}$ & Finance & 30 & $\begin{array}{l}1990- \\
2013\end{array}$ & Codification of laws \\
\hline $\begin{array}{l}\text { Bandiera et al. (2000), financial } \\
\text { lilberalization index }\end{array}$ & $\begin{array}{l}\text { Financial } \\
\text { reform }\end{array}$ & 8 & $\begin{array}{l}1970- \\
1994\end{array}$ & Codification of laws \\
\hline $\begin{array}{l}\text { Laeven (2003), financial lilberal- } \\
\text { ization index }\end{array}$ & $\begin{array}{l}\text { Financial } \\
\text { reform }\end{array}$ & 13 & $\begin{array}{l}1988- \\
1998\end{array}$ & $\begin{array}{l}\text { Evaluation from re- } \\
\text { ports }\end{array}$ \\
\hline $\begin{array}{l}\text { Abiad et al. (2008), financial lil- } \\
\text { beralization index }\end{array}$ & $\begin{array}{l}\text { Financial } \\
\text { reform }\end{array}$ & 91 & $\begin{array}{l}1973- \\
2005\end{array}$ & Codification of laws \\
\hline $\begin{array}{l}\text { Lazear (1990), severance pay and } \\
\text { months of notice }\end{array}$ & Labor & 22 & $\begin{array}{l}1956- \\
1984\end{array}$ & $\begin{array}{l}\text { Pay/Months as } \\
\text { proxy }\end{array}$ \\
\hline $\begin{array}{l}\text { Grubb and Wells (1993), indica- } \\
\text { tor for strictness of employment } \\
\text { protection }\end{array}$ & Labor & 11 & 1989 & $\begin{array}{l}\text { Survey, Codifica- } \\
\text { tion of laws }\end{array}$ \\
\hline $\begin{array}{l}\text { Nicoletti et al. (1999), summary } \\
\text { indicator of regulation and em- } \\
\text { ployment protection legislation }\end{array}$ & $\begin{array}{l}\text { Labor, } \\
\text { product } \\
\text { market } \\
\text { regulation }\end{array}$ & 21 & $\begin{array}{l}\text { late } \\
1980 \text { s } \\
\text { and } \\
1998\end{array}$ & $\begin{array}{l}\text { Survey, Codifica- } \\
\text { tion of laws }\end{array}$ \\
\hline
\end{tabular}




\begin{tabular}{|c|c|c|c|c|}
\hline Study and indicator(s) & Field & Countries & $\begin{array}{l}\text { Time- } \\
\text { span }\end{array}$ & $\begin{array}{l}\text { Construction } \\
\text { method }\end{array}$ \\
\hline $\begin{array}{l}\text { Forteza and Rama (1999), labor } \\
\text { market rigidity indicator }\end{array}$ & Labor & 119 & $\begin{array}{l}1970- \\
1999\end{array}$ & $\begin{array}{l}\text { Number of con- } \\
\text { ventions signed as } \\
\text { proxy }\end{array}$ \\
\hline $\begin{array}{l}\text { Botero et al. (2004), employment } \\
\text { laws, social security laws and in- } \\
\text { dustrial relations laws index }\end{array}$ & Labor & 85 & 1997 & Codification of laws \\
\hline $\begin{array}{l}\text { Howell }(2005) \text {, summary indica- } \\
\text { tor of strictness of employment } \\
\text { protection laws }\end{array}$ & Labor & 12 & 2003 & Survey \\
\hline $\begin{array}{l}\text { Deakin et al. (2007), CBR labor } \\
\text { regulation index }\end{array}$ & Labor & 5 & $\begin{array}{l}1970- \\
2006\end{array}$ & Codification of laws \\
\hline $\begin{array}{l}\text { Armour et al. (2009), CBR } \\
\text { worker, shareholder and creditor } \\
\text { protection index }\end{array}$ & $\begin{array}{l}\text { Labor, Fi- } \\
\text { nance }\end{array}$ & 5 & $\begin{array}{l}1970- \\
2006\end{array}$ & Codification of laws \\
\hline $\begin{array}{l}\text { Deakin et al. (2014), CBR labour } \\
\text { regulation index }\end{array}$ & Labor & 6 & $\begin{array}{l}1970- \\
2010\end{array}$ & Codification of laws \\
\hline $\begin{array}{l}\text { Adams et al. (2015), CBR labour } \\
\text { regulation index }\end{array}$ & Labor & 117 & $\begin{array}{l}1990- \\
2013\end{array}$ & Codification of laws \\
\hline $\begin{array}{l}\text { International Labour Office } \\
(2015) \text {, CBR labour regulation } \\
\text { index }\end{array}$ & Labor & 63 & $\begin{array}{l}1993- \\
2013\end{array}$ & Codification of laws \\
\hline $\begin{array}{l}\text { Malpezzi and Ball (1993), prelim- } \\
\text { inary overall rent control index }\end{array}$ & Housing & 51 & $\begin{array}{l}\text { ca. } \\
1991\end{array}$ & Codification of laws \\
\hline $\begin{array}{l}\text { Djankov et al. (2002a), Procedu- } \\
\text { ral formalism index }\end{array}$ & Housing & 109 & 2000 & Survey \\
\hline
\end{tabular}




\begin{tabular}{|c|c|c|c|c|}
\hline Study and indicator(s) & Field & Countries & $\begin{array}{l}\text { Time- } \\
\text { span }\end{array}$ & $\begin{array}{l}\text { Construction } \\
\text { method }\end{array}$ \\
\hline $\begin{array}{l}\text { Andrews et al. (2011), rent con- } \\
\text { trol and tenant-landlord regula- } \\
\text { tion indicator }\end{array}$ & Housing & 30 & 2009 & Survey \\
\hline $\begin{array}{l}\text { Cuerpo et al. (2014), rent control } \\
\text { and tenant-landlord relationship } \\
\text { indicator }\end{array}$ & Housing & 27 & 2012 & $\begin{array}{l}\text { Codification of } \\
\text { laws, Survey }\end{array}$ \\
\hline $\begin{array}{l}\text { Miletić (2016), state intervention } \\
\text { in housing market }\end{array}$ & Housing & 4 & $\begin{array}{l}1918- \\
1928\end{array}$ & Codification of laws \\
\hline $\begin{array}{l}\text { Weber (2017), rental market reg- } \\
\text { ulation index }\end{array}$ & Housing & 18 & $\begin{array}{l}1973- \\
2014\end{array}$ & Codification of laws \\
\hline $\begin{array}{l}\text { Kholodilin (2020), rental market } \\
\text { regulation index }\end{array}$ & Housing & 101 & $\begin{array}{l}1910- \\
2020\end{array}$ & Codification of laws \\
\hline $\begin{array}{l}\text { Glaeser et al. (2004), several indi- } \\
\text { cators for institutions }\end{array}$ & $\begin{array}{l}\text { Legal insti- } \\
\text { tutions }\end{array}$ & varies & varies & varies \\
\hline $\begin{array}{l}\text { Zaaruka et al. (2011), property } \\
\text { rights, political freedom and ju- } \\
\text { dicial independence index }\end{array}$ & $\begin{array}{l}\text { Legal insti- } \\
\text { tutions }\end{array}$ & 1 & $\begin{array}{l}1984- \\
2008\end{array}$ & Codification of laws \\
\hline $\begin{array}{l}\text { Bremus and Kliatskova (2020), le- } \\
\text { gal harmonization index }\end{array}$ & $\begin{array}{l}\text { Legal insti- } \\
\text { tutions }\end{array}$ & 28 & $\begin{array}{l}1999- \\
2015\end{array}$ & Codification of laws \\
\hline $\begin{array}{l}\text { Freedom House (2020), Freedom } \\
\text { in the World Index }\end{array}$ & $\begin{array}{l}\text { Legal insti- } \\
\text { tutions }\end{array}$ & $\begin{array}{l}\text { varies } \\
\text { (currently } \\
195)\end{array}$ & $1972-$ & Survey \\
\hline $\begin{array}{l}\text { Botero and Ponce (2011), Rule of } \\
\text { Law Index }\end{array}$ & $\begin{array}{l}\text { Legal insti- } \\
\text { tutions }\end{array}$ & $\begin{array}{l}\text { varies } \\
\text { (currently } \\
126 \text { ) }\end{array}$ & $2012-$ & Survey \\
\hline
\end{tabular}




\begin{tabular}{|c|c|c|c|c|}
\hline Study and indicator(s) & Field & Countries & $\begin{array}{l}\text { Time- } \\
\text { span }\end{array}$ & $\begin{array}{l}\text { Construction } \\
\text { method }\end{array}$ \\
\hline $\begin{array}{l}\text { Nicholson (2008) Antitrut Law } \\
\text { Index }\end{array}$ & $\begin{array}{l}\text { Competition } \\
\text { Law }\end{array}$ & 52 & 2003 & Codification of laws \\
\hline $\begin{array}{l}\text { Hylton and Deng (2007) Scope } \\
\text { Index }\end{array}$ & $\begin{array}{l}\text { Competition } \\
\text { Law }\end{array}$ & 102 & $\begin{array}{l}2001- \\
2004\end{array}$ & Codification of laws \\
\hline $\begin{array}{l}\text { Buccirossi et al. (2011) Competi- } \\
\text { tion Policy Indexes }\end{array}$ & $\begin{array}{l}\text { Competition } \\
\text { Law }\end{array}$ & 13 & $\begin{array}{l}1995- \\
2005\end{array}$ & Codification of laws \\
\hline $\begin{array}{l}\text { Borrell and Jimenez (2008) Four } \\
\text { Indicators }\end{array}$ & $\begin{array}{l}\text { Competition } \\
\text { Law }\end{array}$ & 47 & 2004 & Codification of laws \\
\hline Voigt (2009) Four New Indicators & $\begin{array}{l}\text { Competition } \\
\text { Law }\end{array}$ & 59 & 2008 & Survey \\
\hline $\begin{array}{l}\text { Alemani et al. (2016) Indicators } \\
\text { for Competition Law and Policy }\end{array}$ & $\begin{array}{l}\text { Competition } \\
\text { Law }\end{array}$ & 49 & 2013 & Survey \\
\hline $\begin{array}{l}\text { Bradford et al. (2019) Competi- } \\
\text { tion Law Index }\end{array}$ & $\begin{array}{l}\text { Competition } \\
\text { Law }\end{array}$ & 126 & $\begin{array}{l}1889- \\
2010\end{array}$ & Codification of laws \\
\hline $\begin{array}{l}\text { Djankov et al. (2002b), number of } \\
\text { procedures, cost and time }\end{array}$ & $\begin{array}{l}\text { Regulation } \\
\text { of entry }\end{array}$ & 85 & 1999 & Survey \\
\hline $\begin{array}{l}\text { Nicoletti and Scarpetta (2003), } \\
\text { different indicators for product } \\
\text { market regulation }\end{array}$ & $\begin{array}{l}\text { Product } \\
\text { market } \\
\text { regulation }\end{array}$ & 18 & $\begin{array}{l}1980- \\
2000\end{array}$ & Own evaluation \\
\hline $\begin{array}{l}\text { Cooter and Ginsburg (2003), } \\
\text { number of words }\end{array}$ & $\begin{array}{l}\text { Extent of } \\
\text { laws }\end{array}$ & 15 & $\begin{array}{l}\text { ca. } \\
2003\end{array}$ & Codification of laws \\
\hline $\begin{array}{l}\text { Mulligan and Shleifer (2005), KB } \\
\text { of laws }\end{array}$ & $\begin{array}{l}\text { Extent of } \\
\text { laws }\end{array}$ & $\begin{array}{l}37 \quad \text { US } \\
\text { states }\end{array}$ & $\begin{array}{l}\text { ca. } \\
2002\end{array}$ & Size of files \\
\hline $\begin{array}{l}\text { Djankov et al. (2008), time, cost } \\
\text { and efficiency of enforcement }\end{array}$ & $\begin{array}{l}\text { Debt en- } \\
\text { forcement }\end{array}$ & 88 & 2002 & Survey \\
\hline
\end{tabular}




\begin{tabular}{l|l|l|l|l}
\hline \multicolumn{1}{l}{ Study and indicator(s) } & Field & Countries & $\begin{array}{l}\text { Time- } \\
\text { span }\end{array}$ & $\begin{array}{l}\text { Construction } \\
\text { method }\end{array}$ \\
\hline $\begin{array}{l}\text { Djankov et al. (2020), Title and } \\
\text { transfer of title indicators }\end{array}$ & $\begin{array}{l}\text { Property } \\
\text { rights }\end{array}$ & 190 cities & 2019 & Codification of laws \\
\hline $\begin{array}{l}\text { Hartlapp (2020), public procure- } \\
\text { ment index }\end{array}$ & $\begin{array}{l}\text { Social Ob- } \\
\text { jectives }\end{array}$ & 2 & $2000-$ & Codification of laws \\
\hline
\end{tabular}

